\title{
Effect of Rht alleles on the tolerance of wheat grain set to high temperature and drought stress during booting and anthesis
}

Article

Accepted Version

Alghabari, F., Lukac, M., Jones, H. E. and Gooding, M. J. (2014) Effect of Rht alleles on the tolerance of wheat grain set to high temperature and drought stress during booting and anthesis. Journal of Agronomy and Crop Science, 200 (1). pp. 36-45. ISSN 1439-037X doi: https://doi.org/10.1111/jac.12038 Available at https://centaur.reading.ac.uk/33964/

It is advisable to refer to the publisher's version if you intend to cite from the work. See Guidance on citing.

Published version at: http://onlinelibrary.wiley.com/doi/10.1111/jac.12038/abstract

To link to this article DOI: http://dx.doi.org/10.1111/jac.12038

Publisher: Wiley

All outputs in CentAUR are protected by Intellectual Property Rights law, including copyright law. Copyright and IPR is retained by the creators or other copyright holders. Terms and conditions for use of this material are defined in the End User Agreement. 


\section{CentAUR}

Central Archive at the University of Reading

Reading's research outputs online 


\section{Effect of Rht alleles on the tolerance of wheat grain set to high temperature and drought stress during booting and anthesis}

F. Alghabari, M. Lukac, H. E. Jones \& M. J. Gooding

School of Agriculture Policy and Development, University of Reading, Earley Gate, PO Box 237, Reading, RG6 6AR, UK

\section{Correspondence}

M.J. Gooding

School of Agriculture Policy and Development, University of Reading, Earley Gate, PO Box 237, Reading, RG6 6AR, UK

Tel.: +44 1183788487

Fax. +441189261244

Email: $\underline{\text { m.j.gooding@reading.ac.uk }}$

3 Tables, 3 Figures 


\section{Abstract}

Factorial pot experiments were conducted to compare the responses of GA-sensitive and GAinsensitive reduced height $(R h t)$ alleles in wheat for susceptibility to heat and drought stress during booting and anthesis. Grain set (grains/spikelet) of near isogenic lines (NILs) was assessed following three day transfers to controlled environments imposing day temperatures $(t)$ from 20 to $40^{\circ} \mathrm{C}$. Transfers were during booting and/or anthesis and pots maintained at field capacity (FC) or had water withheld. Logistic responses $\left(y=c / 1+\mathrm{e}^{-b(t-m)}\right)$ described declining grain set with increasing $t$, and $t_{5}$ was that fitted to give a $5 \%$ reduction in grain set. Averaged over NIL, $t_{5}$ for anthesis at FC was $31.7 \pm 0.47^{\circ} \mathrm{C}$ (S.E.M, 26 d.f.). Drought at anthesis reduced $t_{5}$ by $<2^{\circ} \mathrm{C}$. Maintaining $\mathrm{FC}$ at booting conferred considerable resistance to high temperatures $\left(t_{5}=33.9^{\circ} \mathrm{C}\right)$ but booting was particularly heat susceptible without water $\left(t_{5}=26.5^{\circ} \mathrm{C}\right)$. In one background (cv. Mercia), for NILs varying at the Rht-Dl locus, there was progressive reduction in $t_{5}$ with dwarfing and reduced gibberellic acid (GA) sensitivity (Rht-Dla, tall, 32.7 $\pm 0.72 ; R h t$ $D 1 b$, semi-dwarf, 29.5 $\pm 0.85 ;$ Rht-D1c, severe dwarf, $24.2 \pm 0.72$ ). This trend was not evident for the Rht-B1 locus, or for Rht-Dlb in an alternative background (Maris Widgeon). The GAsensitive severe dwarf $R h t 12$ was more heat tolerant $\left(t_{5}=29.4 \pm 0.72\right)$ than the similarly statured GA-insensitive Rht-Dlc. The GA-sensitive, semi-dwarfing Rht8 conferred greater drought tolerance in one experiment. Despite the effects of Rht-Dl alleles in Mercia on stress tolerance, the inconsistency of the effects over background and locus led to the conclusion that semidwarfing with GA-insensitivity did not necessarily increase sensitivity to stress at booting and flowering. In comparison to effects of semi-dwarfing alleles, responses to heat stress are much more dramatically affected by water availability and the precise growth stage at which the stress is experienced by the plants.

Key words Drought, Gibberellin, Heat stress, Reduced height, Rht, Wheat Running title Rht alleles on heat stress tolerance of wheat 


\section{Introduction}

Predicted increases in the frequency of heat waves and droughts threaten crop production and food security (Wheeler et al. 1996a, Easterling et al. 2000, Porter and Semenov 2005, Semenov, 2007). Cereals are notably susceptible to heat and drought stress at meiosis, coincident with booting, and also during anthesis (Barnabás et al. 2008). Wheat is a particularly susceptible cereal with temperatures above $30^{\circ} \mathrm{C}$ between booting and anthesis causing dramatic reductions in grain set associated with impaired production, viability and functionality of reproductive tissues (Saini and Aspinall, 1982a, Saini et al. 1983, Wheeler et al. 1996a, Ferris et al. 1998).

It is possible that sensitivity of wheat fertility to heat and drought stress is partly due to the widespread use of the semi-dwarfing alleles that underpinned much of the wheat Green Revolution. Rapid increases in wheat yields in major growing areas of the world from the 1960s to the 1990 s were associated with: reducing wheat statures to less than $1.0 \mathrm{~m}$; increasing harvest index and reducing lodging risk in fertile and humid conditions (Gooding, 2009). By the 1990's $80 \%$ of registered wheat cultivars contained a semi-dwarfing $R h t$ allele and in over $90 \%$ of these cases the allele was either $R h t-B 1 b$ or $R h t-D 1 b$ (Worland et al. 1998). The Rht- 1 alleles encode for DELLA proteins (Peng et al. 1999) which repress gibberellic acid (GA)-responsive growth (Murase et al. 2008, Achard and Genschik, 2009). Both Rht-Blb and Rht-Dlb: are from the Japanese wheat 'Norin 10'; reduce sensitivity to endogenous gibberellins (GA); reduce final crop height by about 15\% in UK field conditions (Gooding et al. 2012); and contain single nucleotide substitutions causing premature stop codons in the $\mathrm{N}$-terminal coding region, possibly leading to more repressive forms of DELLA (Pearce et al. 2011). More potent alleles, giving severe dwarfism, are available at both loci: Rht-Blc from 'Tom thumb' produces a predicted 30-amino-acid insertion within DELLA (Pearce et al. 2011), and a 50\% reduction in height; and Rht-Dlc from 'Ai-bian' (Borner et al. 1997) over-expresses Rht-Dlb through increased gene copy number (Pearce et al. 2011), and reduces height by about 55\%. Despite, their widespread use, early reviews suggested that both Rht-Blb and $R h t-D 1 b$ may confer 
increased sensitivity to drought and heat stress (Gale and Youssefian, 1985). In particular, it is known that GA-signalling is critical for the normal development and functioning of reproductive tissues (e.g. Mutasa-Gottgens and Hedden, 2009) and interference with GA-signalling may explain why preliminary work (Law et al. 1981, Law and Worland, 1985) found Rht-Blb, Rht$D 1 b$, and Rht-Blc to be associated with marked reductions in fertility in response to increased temperatures (e.g. $30 / 27^{\circ} \mathrm{C}$ day/night for $18 \mathrm{~h}$ days) during booting. Further circumstantial evidence is that Norin 10 alleles have reduced selection frequencies in areas of southern Europe, where there is an increased likelihood of high temperature events during meiosis (Worland, 1986), and Sip et al. (2011) note a recent decline in the use of Rht-Blb and Rht-Dlb in areas further north, in central Europe.

Given the prevalence of GA-insensitive dwarfing alleles in the world's wheat production, and the possibility that they may increase sensitivity to stresses predicted to become more frequent in climate change scenarios, there is an urgent need to clarify the effects of GAinsensitivity on tolerance to high temperature and drought during booting and anthesis. Here we compare grain set in near-isogenic lines (NILs) varying for Rht-1 semi- and severe dwarfing alleles with alleles that retain GA-sensitivity: $r h t($ tall); the semi-dwarfing $R h t 8$ present in many Southern European wheats (Worland et al. 1998) that may interfere with brassinosteroid signalling (Gasperini et al. 2012); and Rht12, a severe-dwarfing (about 60\% height reduction), gamma ray-induced allele from 'Karcagi 522' (Korzun et al. 1997).

\section{Materials and methods}

Growing conditions and experimental design

Three complete factorial pot experiments (Table 1) at the Plant Environment Laboratory, University of Reading, UK ( $51^{\circ} 27^{\prime} \mathrm{N}$ latitude, $00^{\circ} 56^{\prime} \mathrm{W}$ longitude), compared NILs of winter wheat receiving a range of temperatures. Other factors included timing of stress (Expt 2) and irrigation (Expts 2 and 3). Experiment 3 also included the use of crossing bags as a factor to test 
the effect of preventing out-crossing, and hence inter and intra pot interference on grain set, after the exposure to stress. All experiments used plastic pots (180 mm diameter; 4 litre volume) containing 2:1:2:0.5 of vermiculite: sand: gravel: compost mixed with Osmocote slow release granules $\left(2 \mathrm{~kg} \mathrm{~m}^{-3}\right)$ containing a ratio of 15: 11: 13:2 of N: $\mathrm{P}_{2} \mathrm{O}_{5}: \mathrm{K}_{2} \mathrm{O}: \mathrm{MgO}$. The weight of each pot was recorded after it had been flooded then left until dripping from the base had ceased after $24 \mathrm{~h}$, to determine the weight at field capacity (FC). Weight of growing media per pot averaged $2.60 \mathrm{~kg}$ and $3.05 \mathrm{~kg}$ at 0 and $100 \% \mathrm{FC}$ respectively. Seven seeds were sown per pot which allowed thinning to four plants at the two leaf stage. The pots were maintained outside under a net in a completely randomised design, and with guard, discard pots of wheat placed around the perimeter of the experiment. Fungicide was applied as and when required to control powdery mildew (Blumeria graminis f. sp. tritici). Pots were watered twice daily by an automatic drip irrigation system to maintain field capacity (FC). All experimental treatments comprised transferring pots to matched $1.37 \times 1.47 \mathrm{~m}^{2}$ Saxil growth cabinets at 15:30h GMT for three $16 \mathrm{~h}$ day (700 mM photon $\mathrm{m}^{-2} \mathrm{~s}^{-1} ; 70+/-2 \%$ relative humidity; 350-360 $\mu \mathrm{mol} \mathrm{CO}_{2} \mathrm{~mol}^{-1}$ air), $8 \mathrm{~h}$ night cycles $\left(8^{\circ} \mathrm{C}\right.$ below day temperature) before returning to the original randomized position outside. The approach was similar to that of Saini and Aspinall (1982b) in that stress was applied for three days to detect effects of tolerance, rather than escape due to variations in growth stage within spikes (Lukac et al. 2012). Timing of transfer depended on the growth stage of the pot and treatment: when at least two main stems had just reached the end of booting (GS 47 or 49; Zadoks et al. 1974; Expts 2 and 3), and when at least two ears per pot had just reached full anthesis (GS 69; Expts 1 and 2). In Expt 3 cellophane crossing bags $(55 \times 190 \mathrm{~mm}$, ref. no. PKS 15000-00; Focus Packaging and Design, Louth, UK) were placed over all the ears in half of the pots before transfer to the cabinets at booting.

Whilst in the cabinets, when irrigation was provided, it was applied by an automatic irrigation system to broadly maintain pot weight of the pots in the highest temperature treatment. Pots were weighed as they went in to, and came out of the cabinets. The attempt to maintain pot 
weight by irrigation in the highest temperature treatment was broadly successful (Fig. 1), whilst the reduction in weight of the non-irrigated pots indicated the imposition of a severe drought by the end of the three days.

Stems in a pot were scored and tagged for their growth stage when the pot was transferred. Ears tagged as at different growth stages when transferred to the cabinets were harvested and assessed from each pot separately. Numbers of ears and spikelets were counted before the ears were threshed, cleaned and counted by hand. For the anthesis treatment, data from those ears assessed as at GS 69 on transfer were omitted from further analyses on the basis that the earliest flowers on such ears could have been fertilized four or five days earlier (Lukac, personal communication), and hence beyond the susceptible growth stage (Saini and Aspinall, 1982b, Stone and Nicolas, 1995a,b,c). Similarly for the booting treatment, data from ears scored earlier than GS 41 at transfer were not included in further analysis. Following these omissions, each pot produced an average of 9 ears within the selected growth stage range, each with an average of 19 spikelets.

\section{Statistical methods}

The effects of stress treatments on grains per pot reflected grains per spikelet rather than ear number or spikelet number, so all analyses concern effects on mean number of grains per spikelet. Temperature treatments within an experiment were not replicated in different growth cabinets so initial separate ANOVAs, using pot means as the experimental unit, were restricted to the factorial combinations represented at each temperature (NIL in Expt 1, NIL $\times$ timing $\times$ irrigation in Expt 2, NIL $\times$ irrigation $\times$ bagging in Expt 3). No ANOVA was conducted at the highest temperature in any experiment due to excessive variance heterogeneity.

In fitting the response of grains per spikelet to temperature it was presumed from previous work that the minimum day: night temperature of $20: 12^{\circ} \mathrm{C}$ would not be a constraint to grain set (Wheeler et al. 1996b; Subedi et al. 2001; Prasad et al. 2008), and also that increasing the 
temperature would only cause a significant reduction in grain set after a critical temperature had been exceeded (Wheeler et al. 1996b; Craufurd et al. 2013). Previous fits to these types of data set have involved curved responses (e.g. Wheeler et al. 1996b), or linear declines from a maximum after a critical temperature had been reached (e.g. Craufurd et al. 2013). Here, the The logistic function [1] was chosen as responses could not justify $(P<0.05)$ more than three parameters, and the fits routinely explained more variance than other three parameter models tested (e.g. a linear decline from a maximum, or the gompertz model with constant omitted). A critical temperature was arbitrarily chosen as that which caused a 5\% reduction [2] in grain set.

$$
y=\frac{c}{1+\exp \left(-b\left(^{o} C-m\right)\right)}
$$

Where $c$ gives the maximum $y$ when there is no heat stress, $b$ is the logistic rate scalar, and $m$ is the temperature at which $y$ is $50 \%$ of $c$ i.e. $m=$ temperature $(t)_{50}$.

$$
\text { critical temperature }=t_{5}=\frac{b m+2.944}{b}
$$

Finally, a combined residual maximum likelihood (REML) analysis over all experiments was conducted on the estimates of $t_{5}$ and $m$ (i.e. $t_{50}$ ) with a fixed model of the main effects and two factor interactions among NIL $\times$ Irrigation $\times$ Timing, with the three factor interaction and effects of year (random) assigned to error (24 d.f.).

\section{Results}

Experiment 1 
Increasing day temperature from $30^{\circ} \mathrm{C}$ to $35^{\circ} \mathrm{C}$ for three days around anthesis decreased grain numbers per spikelet in all four lines (Fig. 2a-d). The logistic function appeared broadly sufficient but the reduced number of treatments in the sensitive range between $30^{\circ} \mathrm{C}$ and $40^{\circ} \mathrm{C}$ led to estimates of $b$ and $m$ being highly correlated and very dependent on observations at $35^{\circ} \mathrm{C}$. At $35^{\circ} \mathrm{C}$ the GA-sensitive alleles (Fig. 2a,b) had similar levels of grain set, which were significantly $(P<0.05)$ higher than that achieved by the GA-insensitive Rht-Dlb (Fig. $2 \mathrm{c})$ and, most notably the severe dwarf Rht-Dlc (Fig. 2d). In the case of Rht-Dlb, however, the effect was insufficient to alter the estimate of the critical temperature (around $32^{\circ} \mathrm{C}$ ), relative to the GA-sensitive lines.

\section{Experiment 2}

For each of the most discriminatory temperatures $\left(30^{\circ} \mathrm{C}, 33^{\circ} \mathrm{C}, 36^{\circ} \mathrm{C}\right)$ there were highly significant $(P<0.01)$ interactions between irrigation and timing of stress on grains per spikelet (Fig. 2e-r; Fig. 3a-h). Averaged over NIL, withholding water had a more dramatic effect on critical temperature at booting, than at anthesis (Fig. 2e-r; Fig. 3a-h). There were, however, NIL $\times$ Timing $\times$ Irrigation interactions $(P<0.05)$ at $33^{\circ} \mathrm{C}$, and NIL $\times$ timing $(P<0.001)$ and $\mathrm{NIL} \times$ Irrigation $(P<0.01)$ interactions at $36^{\circ} \mathrm{C}$. There were a number of contributory effects to these interactions: the effect of drought at booting tended to be more severe in the M. Widgeon NILs (Fig. 3a-d) than in the Mercia NILs (Fig. 2e-k); although withholding water at anthesis generally had little effect on critical temperature, this was not the case for the GA-insensitive Mercia+Rht$D 1 b$ (Fig. 2p) and M. Widgeon $+R h t-B 1 c$ (Fig. 3h); the GA-sensitive Mercia $+R h t 8$ showed marked tolerance of drought at booting, even at temperatures as high as $36^{\circ} \mathrm{C}$ (Fig. $2 \mathrm{f}$ ). Mercia + Rht-Dlc appeared more sensitive to increasing temperature (Fig. 2k,r) than other lines; consistent with its performance at anthesis in Expt 1. This was not due to severe dwarfism per se, as can be deduced by comparison with both the GA-sensitive Mercia+Rht12 (Fig. 2g,n) and the GA-insensitive Rht-B1c (Fig. 2j,g). 


\section{Experiment 3}

At both $33^{\circ} \mathrm{C}$ and $36^{\circ} \mathrm{C}$ there were NIL $\times$ Irrigation interactions $(P<0.05,<0.001$ respectively $)$. There was no evidence that semi-dwarfing with GA-insensitive Rht-Blb increased susceptibility to heat and drought in Merica (Fig. 2s,u) or in M. Widgeon (Fig. 3i,j). When irrigated, at $36^{\circ} \mathrm{C}$ $r h t$ (tall) reduced grain set was again particularly evident for $R h t-D l c$ (Fig. 2v), but a major contributor to the interaction with irrigation was the greater susceptibility of $R h t 12$ to drought in this experiment (Fig. 2t).

The use of crossing bags to prevent out-crossing between ears and plants in different pots had no significant $(P>0.05)$ main effect on grain set nor any strong interacting effects with NIL or Irrigation at $33^{\circ} \mathrm{C}$ or $36^{\circ} \mathrm{C}$.

Combined analysis

For critical temperature $\left(t_{5}\right)$ there were strong effects of Timing $\times$ Irrigation $(P<0.001)$, NIL $\times$ Timing $(P=0.002)$, and NIL $\times$ Irrigation $(P<0.001)$. At booting, there was a strong effect of drought, reducing $t_{5}$ to an average of $26.5^{\circ} \mathrm{C} \pm 0.56$ (S.E.M, d.f. $=26$ ). As long as pots were irrigated, however, plants appeared particularly resistant to heat stress at booting with $t_{5}$ extended to $33.9^{\circ} \mathrm{C} \pm 0.50$. At anthesis, drought had a less severe effect $\left(t_{5}=29.9 \pm 0.47\right)$ whilst heat with irrigation $\left(t_{5}=31.7 \pm 0.47\right)$ was more damaging than the same conditions at booting. A contribution to the NIL $\times$ Irrigation effect was the reduction in $t_{5}$ of Mercia $+R h t-D 1 b$ when water was withheld, particularly when compared to the response of $R h t 8$ (Table 2). When averaged over Irrigation and Timing there was a progressive reduction in $t_{5}$ with degree of dwarfing associated with Rht-Dl allele in Mercia from $r h t$ (tall), to Rht-D1b, to Rht-Dlc (Table 2). There was however, no similar progression with alleles at the Rht-B1 locus, or any reduction in average $t_{5}$ with GA-insensitive alleles in M. Widgeon. 
For the logistic time scalar i.e. $t_{50}$ there were strong effects of Timing $\times$ Irrigation $(P<0.001)$, and NIL $\times$ Timing $(P<0.001)$, but not, in contrast to $t_{5}$, for NIL $\times$ Irrigation $(P=0.56)$. Combining drought with heat was again particularly damaging at booting (Water withheld, $t_{50}=$ $31.3 \pm 0.65$; irrigated $=36.9 \pm 0.65)$ compared with at anthesis (Water withheld, $t_{50}=34.2 \pm$ 0.70 ; irrigated $=36.3 \pm 0.64$ ). A major contributor to the NIL $\times$ Timing effect was the relative tolerance of $R h t 8$ to stresses at booting (Table 3). When averaged of Irrigation and Timing only $R h t-D 1 c$ had significantly lower $t_{50}$ than $\operatorname{rht}($ tall $)$.

\section{Discussion}

The primary purpose of these experiments was to determine whether the adoption of GAinsensitive lines had reduced the heat and/or drought stress tolerance of winter wheat, as had been suggested by preliminary work by Law et al. (1981) and Law and Worland (1985). The dramatic reductions in grain set previously reported were not found. There was some evidence that dwarfing alleles at the Rht-Dl locus could reduce grain set under stressed conditions compared with GA-sensitive lines of comparable heights. However, over different backgrounds and loci, semi-dwarfing with GA-insensitivity conferred by the Norin 10 alleles was not consistently associated with poor grain set under stress. In comparison to effects of semidwarfing alleles, responses to heat stress are much more dramatically affected by water availability and the precise growth stage at which the stress is experienced by the plants.

\section{Effects of environment}

These results confirm the susceptibility of wheat to heat and drought stress during booting, and again at flowering (Westgate et al. 1996; Barnabás et al. 2008). Drought, with or without heat, can increase spike and floret concentrations of abscisic acid (ABA), which can be related closely with poor grain set (Westgate et al. 1996; Weldearegay et al. 2012). Additionally, heat and drought can reduce photosynthesis, and the subsequent dilution of sucrose in the ear can be 
associated with floret abortion (Barnabás et al. 2008). Furthermore, temperatures above $30^{\circ} \mathrm{C}$ during meiosis can interfere with division and lead to abnormal pollen development (Saini et al. 1984). Young et al. (2001) suggest induction of protective heat shock proteins in developing and mature pollen grain can be insufficient to meet demand following heat stress; and that this failure correlates with the poor thermotolerance of pollen and reduced grain set.

The results presented here are consistent with the findings of Saini and Aspinall (1981) i.e. that grain set in wheat is particularly sensitive to water deficits during booting. There is a clear interaction with heat. Higher temperatures increased the water deficit, and presumably also the duration of drought. The more rapid onset of drought would also have affected the precise timing of stress. Drought reduces capacity for evaporative cooling, and hence lessons possible escape from high air temperatures (Reynolds and Trethowan, 2007; Craufurd et al. 2013).

Nonetheless, the much greater effect of withholding water during booting, compared with drought during anthesis suggests a specific heightened sensitivity to drought during booting; presumed to be broadly coincident with completion of meiosis (Saini and Aspinall, 1981, 1982b; Westgate et al. 1996).

Our results confirm and support a critical temperature during anthesis for grain set in irrigated wheat of around $31^{\circ} \mathrm{C}$ (Wheeler et al. 1996b, Porter and Gawith, 1999), despite different models used to fit responses and the alternative genotypes used in earlier work.

\section{Effects of $R h t$ allele}

The occasional reductions in grain set at some discriminatory temperatures for $R h t-B 1 b$ and $R h t$ $D 1 b$, and the progressive reduction in average $t_{5}$ for $r h t$ (tall), Rht-Dlb to $R h t-D l c$ in Mercia do suggest some risk for reduced heat stress tolerance with the use of GA-insensitive alleles. Moreover, the repeatedly compromised grain set and increased susceptibility to heat stress of $R h t-D 1 c$, an allele associated with over expression of $R h t-D 1 b$ (Pearce et al. 2011), is consistent with the importance GA-mediated responses in floral development and fertilization processes 
(Hou et al. 2008, Mutasa-Gottgens and Hedden, 2009). However, the similarities in responses of $r h t($ tall), Rht-Blb, Rht-Dlb and Rht-Blc when averaged over Mercia and Maris Widgeon backgrounds, appear to contradict the preliminary findings of Law et al. (1981) and Law and Worland (1985) that GA-insensitive alleles confer very marked intolerance of heat stress at booting. It is difficult to explain this inconsistency except, perhaps, to highlight the potential importance of growth stage and water status variations. Amongst all the lines used here, dwarfing is associated with delayed anthesis (Gooding et al. 2012) and it was important, therefore, to time transfers of pots on GS rather than on calendar day. Our findings would suggest that the 'normal' expression of the Rht-Dlb or Rht-Blb allele singularly, within the polyploidy context, is insufficient to routinely compromise grain set at high or benign temperatures. This reduced risk is further supported by the robust fertility of $R h t-B 1 c$ reported here which was in spite severe dwarfing (but less so than Rht-Dlc) with GA-insensitivity.

There are several reasons why dwarfing per se could influence tolerance to heat stress. Amongst the alleles used here, above-ground biomass at anthesis has been linearly-related to height (Gooding et al. 2012). The reduced biomass at anthesis of dwarfed lines could have influenced assimilate availability, evaporative cooling, and water use. More specifically, DELLA protein has been implicated in tolerance through reducing growth rates during periods of stress (Achard et al. 2006). However, the shortest plants were from Mercia+Rht12, which produced a temperature response of grains per spikelet much more similar to $r h t($ tall), than to Rht-Dlc. i.e. in these experiments, stature per se can only have been a minor contributor to the effects of allele on heat stress tolerance.

The critical temperature of $31^{\circ} \mathrm{C}$ just before anthesis estimated by Wheeler et al. (1996) was for an elite, semi-dwarf line carrying one of the Norin 10 GA-insensitive alleles $(R h t-D 1 b)$. We have no general basis to increase this critical temperature for more GA-sensitive lines. However, the apparent tolerance of $R h t 8$ to drought at booting requires further investigation. The effect cannot be ascribed readily to GA-sensitivity given the comparative intolerance of the other GA- 
sensitive lines: $r h t($ tall) and $R h t 12$. Rht8 appears to reduce height through reduced sensitivity to brassinosteroids (Gasperini et al. 2012). Amongst many processes, brassinosteroid signalling is important for stomatal development (Casson et al. 2012), which would have implications for water use and drought tolerance. However, the links between any modifications of stomatal development and the drought tolerance of $R h t 8$ reported here remain highly speculative. It is notable that in the field, near isogenic lines with $R h t 8$ have produced inferior yields to those with $R h t-D 1 b$ and $R h t-B 1 b$ where maturation has been into a terminal drought (Lanning et al. 2012).

In conclusion, although there are significant NIL $\times$ environment interactions within experiments it is difficult to routinely ascribe these to effects of GA-sensitivity or height. Combined analyses over all experiments and genetic backgrounds do not suggest that reducing sensitivity to GA necessarily confers reduced tolerance to heat and drought in pot experiments. In heat and drought-stressed field conditions, reports of negative impacts of GA-insensitive alleles on yield (i.e. $R h t-D 1 b$ and $R h t-B 1 b$ yield less than $r h t($ tall)) are very rare (Butler et al. 2005, Matthews et al. 2006); thus supporting our suggestion that semi-dwarfing with reduced sensitivity to GA does not necessarily confer special intolerance of grain set to stresses at booting and anthesis. It would seem from our experiments that any differences in the field are more likely to be due to differences in water availability, possibly as a result of effects on root architecture and function that cannot be expressed within the confines of a pot (Wojciechowski et al. 2009), and/or adaptive significance of the timing of the onset and duration of susceptible growth stages.

\section{Acknowledgements}

The authors are grateful to Mr JL Hansen and Ms CJ Hadley for technical assistance, to Professor JW Snape, John Innes Centre for supplying the near-isogenic lines, and to Dr B Brak for comments in the development of this manuscript. 


\section{References}

Achard, P., and P. Genschik, 2009: Releasing the brakes of plant growth: how GAs shutdown DELLA proteins. J. Exp. Bot. 60, 1085-1092.

Achard, P., H. Cheng, L. De Grauwe, J. Decat, H. Schoutteten, T. Moritz, D. Van der Straeten, J.R. Peng, and N.P. Harberd, 2006: Integration of plant responses to environmentally activated phytohormonal signals. Science 311, 91-94.

Barnabas, B., K. Jager, and A. Feher, 2008: The effect of drought and heat stress on reproductive processes in cereals. Plant Cell Environ. 31, 11-38.

Borner, A., M. Roder, and V. Korzun, 1997: Comparative molecular mapping of GA insensitive Rht loci on chromosomes 4B and 4D of common wheat (Triticum aestivum L.). Theor. Appl. Genet. 95, 1133-1137.

Butler, J.D., P.F. Byrne, V. Mohammadi, P.L. Chapman, and S.D. Haley, 2005: Agronomic performance of Rht alleles in a spring wheat population across a range of moisture levels. Crop Sci. 45, 939-947.

Casson, S.A., and A.M. Hetherington, 2012: GSK3-like kinases integrate brassinosteroid signaling and stomatal development. Sci. Signal. 5, 30.

Craufurd, P.Q., V. Vadez, S.V. Krishna Jagadish, P.V. Vara Prasad, and M. Zaman-Allah, 2013: Crop science experiments designed to inform crop modeling. Agric. For. Meteorol. 170, 818.

Easterling, D.R., G.A. Meehl, C. Parmesan, S.A. Changnon, T.R. Karl, and L.O. Mearns, 2000: Climate extremes: Observations, modeling, and impacts. Science 289, 2068-2074.

Ferris, R., R.H. Ellis, T.R. Wheeler, and P. Hadley, 1998: Effect of high temperature stress at anthesis on grain yield and biomass of field-grown crops of wheat. Ann. Bot. 82, 631-639.

Gale, M.D., and S. Youssefian, 1985: Dwarfing genes in wheat. In: Russell GE (Ed.) Progress in Plant Breeding 1. Butterworths, London, pp. 1-35. 
Gasperini, D., A. Greenland, P. Hedden, R. Dreos, W. Harwood, and S. Griffiths, 2012: Genetic and physiological analysis of Rht8 in bread wheat: an alternative source of semi-dwarfism with a reduced sensitivity to brassinosteroids. J. Exp. Bot. 63, 4419-4436.

Gooding, M.J., 2009: The wheat crop. In: K Khan, P R Shewry (eds) Wheat: Chemistry and Technology, 4th edn. AACC International, Minnesota. pp. 35-70.

Gooding, M.J., M. Addisu, R.K. Uppal, J.W. Snape, and H.E. Jones, 2012: Effect of wheat dwarfing genes on nitrogen use efficiency. J. Agric. Sci. 150, 3-22.

Korzun, V., M. Roder, A.J. Worland, and A. Borner, 1997: Intrachromosomal mapping of genes for dwarfing (Rht12) and vernalization response (Vrn1) in wheat by using RFLP and microsatellite markers. Plant Breed. 116, 227-232.

Lanning, S.P., J.M. Martin, R.N. Stougaard, F.R. Guillen-Portal, N.K. Blake, J.D. Sherman, A.M. Robbins, K.D. Kephart, P. Lamb, G.R. Carlson, M. Pumphrey, and L.E. Talbert, 2012: Evaluation of near-isogenic lines for three height-reducing genes in hard red spring wheat. Crop Sci. 52, 1145-1152.

Law, C.N., and A.J. Worland, 1985: An effect of temperature on the fertility of wheats containing the dwarfing genes Rht1, Rht2, and Rht3. Plant Breeding Institute Annual Report 1984. Cambridge: Plant Breeding Institute. pp. 69-71.

Law, C.N., J.W. Snape, and A.J. Worland, 1981: Reduced fertility of wheat associated with Rht3. Plant Breeding Institute Annual Report 1980. Cambridge: Plant Breeding Institute. pp. 72-73.

Lukac, M., M.J. Gooding, S. Griffiths, and H.E. Jones, 2012: Asynchronous flowering and within-plant flowering diversity in wheat and the implications for crop resilience to heat. Ann. Bot. 109, 843-850.

Mathews, K.L., S.C. Chapman, R. Trethowan, R.P. Singh, J. Crossa, W. Pfeiffer, M. van Ginkel, and I. DeLacy, 2006: Global adaptation of spring bread and durum wheat lines near-isogenic for major reduced height genes. Crop Sci. 46, 603-613. 
Murase, K., Y. Hirano, T.P. Sun, and T. Hakoshima, 2008: Gibberellin-induced DELLA recognition by the gibberellin receptor GID1. Nature 456, 459-U15.

Mutasa-Gottgens, E, and P. Hedden, 2009: Gibberellin as a factor in floral regulatory networks. J. Exp. Bot. 60, 1979-1989.

Pearce, S., R. Saville, S.P. Vaughan, P.M. Chandler, E.P. Wilhelm, C.A. Sparks, N. Al-Kaff, A. Korolev, M.I. Boulton, A.L. Phillips, P. Hedden, P. Nicholson, and S.G. Thomas, 2011: Molecular characterization of Rht-1 dwarfing genes in hexaploid wheat. Plant Physiol. 157, $1820-1831$.

Peng, J.R., D.E. Richards, N.M. Hartley, G.P. Murphy, K.M. Devos, J.E. Flintham, J. Beales, L.J. Fish, A.J. Worland, F. Pelica, D. Sudhakar, P. Christou, J.W. Snape, M.D. Gale, and N.P. Harberd, 1999. 'Green revolution' genes encode mutant gibberellin response modulators. Nature 400, 256-261.

Porter, J.R., and M. Gawith, 1999: Temperatures and the growth and development of wheat: a review. Eur. J. Agron. 10, 23-36.

Porter, J.R., and M.A. Semenov, 2005: Crop responses to climatic variation. Philos. Trans. R. Soc. B-Biol. Sci. 360, 2021-2035.

Prasad, P.V.V., S.R. Pisipati, Z. Ristic, U. Bukovnik, and A.K. Fritz, 2008: Impact of night time temperature on physiology and growth of spring wheat. Crop Sci. 48, 2372-2380.

Reynolds, M.P., and R.M. Trethowan, 2007: Physiological interventions in breeding for adaptation to abiotic stress. In Spiertz JHJ, Struik PC, VanLaar HH (Eds). Scale and Complexity in Plant Systems Research: Gene-Plant-Crop Relations. Wageningen Ur Frontis Series 21, 129-146.

Saini, H.S., and D. Aspinall, 1981: Effect of water deficit on sporogenesis in wheat (Triticum aestivum L.). Ann. Bot. 48, 623-633. 
Saini, H.S., and D. Aspinall D, 1982a: Sterility in wheat (Triticum aestivum L) induced by water deficit or high temperature - possible mediation by abscisic acid. Austral. J. Plant Physiol. 9, 529-537.

Saini, H.S. and D. Aspinall, 1982b: Abnormal sporogenesis in wheat (Triticum aestivum L.) induced by short periods of high temperature. Ann. Bot. 49, 835-846.

Saini, H.S., M. Sedgley, and D. Aspinall. 1983: Effect of heat stress during floral development on pollen tube growth and ovary anatomy in wheat (Triticum aestivum L). Austral. J. Plant Physiol. 10, 137-144.

Saini, H.S., M. Sedgley, and D. Aspinall. 1984: Developmental anatomy in wheat male sterility induced by heat stress, water deficit or abscisic acid. Austral. J. Plant Physiol. 11, 243-253.

Semenov, M.A., 2007: Development of high-resolution UKCIP02-based climate change scenarios in the UK. Agric. For. Meteorol. 144, 127-138.

Sip, V., J. Chrpova, A. Zofajova, Z. Milec, D. Mihalik, K. Pankova, and J.W. Snape, 2011:

Evidence of selective changes in winter wheat in middle-European environments reflected by allelic diversity at loci affecting plant height and photoperiodic response. J. Agric. Sci. 149, 313-326.

Stone, P.J., and M.E. Nicolas, 1995a: Effect of timing of heat stress during grain-filling on two wheat varieties differing in heat tolerance. I. Grain growth. Austral. J. Plant Physiol. 22, 927934.

Stone, P.J., and M.E. Nicolas, 1995b: Comparison of sudden heat stress with gradual exposure to high temperature during grain filling on two wheat varieties differing in heat tolerance. I. Grain growth. Austral. J. Plant Physiol. 22, 935-944.

Stone, P.J., and M.E. Nicolas, 1995c: A survey of the effects of high temperature during grain filling on yield and quality of 75 wheat cultivars. Austral. J. Agric. Res. 46, 475-492.

Subedi, K.D., M.J. Gooding, and P.J. Gregory, 2001: Cultivar variation in boron accumulation and grain set in wheat under the influence of cold temperature. Ann. Appl. Biol. 138, 97-101. 
Independent and Combined Effects of Soil Warming and Drought Stress During Anthesis on Seed Set and Grain Yield in Two Spring Wheat Varieties

Weldearegay, D. F., F. Yan, D. Jiang, and F. Liu, 2012: Independent and combined effects of soil warming and drought stress during anthesis on seed set and grain yield in two spring wheat varieties. J. Agron. Crop Sci. 198, 245-253.

Westgate, M.E., J.B. Passioura, R. and Munns, 1996: Water status and ABA content of floral organs in drought-stressed wheat. Austral. J. Plant Phys. 23, 763-772.

Wheeler, T.R., T.D. Hong, R.H. Ellis, G.R. Batts, J.I.L. Morison, and P. Hadley, 1996a: The duration and rate of grain growth, and harvest index, of wheat (Triticum aestivum $\mathrm{L}$ ) in response to temperature and $\mathrm{CO}_{2}$. J. Exp. Bot. 47, 623-630.

Wheeler, T.R., G.R. Batts, R.H. Ellis, P. Hadley, J.I.L. Morison, 1996b: Growth of the yield of winter wheat (Triticum aestivum) crops in response to $\mathrm{CO}_{2}$ and temperature. J. Agric. Sci. $127,37-48$.

Wojciechowski, T., M.J. Gooding, L. Ramsay, and P.J. Gregory, 2009. The effects of dwarfing genes on seedling root growth of wheat. J. Exp. Bot. 60, 2565-2573.

Worland, A.J. 1986: Gibberellic acid insensitive dwarfing genes in southern European wheats. Euphytica 35, 857-866.

Worland, A.J., V. Korzun, M.S. Roder, M.W. Ganal, and C.N. Law, 1998: Genetic analysis of the dwarfing gene Rht8 in wheat. Part II. The distribution and adaptive significance of allelic variants at the Rht8 locus of wheat as revealed by microsatellite screening. Theor. Appl. Genet. 96, 1110-1120.

Worland, A.J., E.J. Sayers, and V. Korzun, 2001. Allelic variation at the dwarfing gene Rht8 locus and its significance in international breeding programmes. Euphytica 119, 155-159. Young, T.E., J. Ling, C.J. Geisler-Lee, R.L. Tanguay, C. Caldwell, and D.R. Gallie, 2001: Developmental and thermal regulation of maize heat shock protein, HSP101. Plant Physiol. $127,777-791$. 
Zadoks, J.C., T.T. Chang, and C.F. Konzak, 1974. A decimal code for the growth stages of cereals. Weed Res. 44, 415-421. 
Table 1 Experimental designs

\begin{tabular}{|c|c|c|c|c|c|}
\hline \multirow[t]{2}{*}{$\begin{array}{l}\text { Sowing } \\
\text { date }\end{array}$} & \multicolumn{2}{|c|}{ Near isogenic lines } & \multicolumn{2}{|c|}{$\begin{array}{l}\text { Treatments applied in controlled } \\
\text { environments }\end{array}$} & \multirow[t]{2}{*}{$\begin{array}{l}\text { Replic- } \\
\text { ate pots }\end{array}$} \\
\hline & Background & Rht allele & Stress Factors & Levels & \\
\hline \multicolumn{6}{|c|}{ Experiment 1} \\
\hline $24 / 02 / 10$ & Mercia & rht(tall); Rht-D1b; Rht-D1c; Rht12 & $\begin{array}{l}\text { Day temp. }\left({ }^{\circ} \mathrm{C}\right) \\
\text { Timing } \\
\text { Irrigation } \\
\text { Crossing bags }\end{array}$ & $\begin{array}{l}20,25,30,35,40 \\
\text { Anthesis } \\
\text { With } \\
\text { Without }\end{array}$ & 6 \\
\hline \multicolumn{6}{|c|}{ crossing nags } \\
\hline $24 / 12 / 10$ & Mercia & $\begin{array}{l}\text { rht(tall); Rht-B1b, Rht-B1c;Rht-D1b; } \\
\text { Rht-D1c; Rht8; Rht12 }\end{array}$ & Day temp. $\left({ }^{0} \mathrm{C}\right)$ & $20,27,30,33,36,39$ & 2 \\
\hline & Maris Widgeon & rht(tall); Rht-B1b;Rht-B1c; Rht-D1b & $\begin{array}{l}\text { Timing } \\
\text { Irrigation } \\
\text { Crossing bags }\end{array}$ & $\begin{array}{l}\text { Booting; anthesis } \\
\text { With; without } \\
\text { Without }\end{array}$ & \\
\hline \multicolumn{6}{|c|}{ Experiment 3} \\
\hline $19 / 12 / 11$ & $\begin{array}{l}\text { Mercia } \\
\text { Maris Widgeon }\end{array}$ & $\begin{array}{l}r h t(\text { tall); Rht-B1b; Rht-D1c; Rht12 } \\
\text { rht(tall); Rht-B1b }\end{array}$ & $\begin{array}{l}\text { Day temp. }\left({ }^{\circ} \mathrm{C}\right) \\
\text { Irrigation } \\
\text { Timing } \\
\text { Crossing bags }\end{array}$ & $\begin{array}{l}20,27,30,33,36,39 \\
\text { With; without } \\
\text { Booting } \\
\text { With, without }\end{array}$ & 2 \\
\hline
\end{tabular}


Table 2 Effects of timing, irrigation and Rht allele within near-isogenic line (NILs) on the temperatures fitted to give a $5 \%$ reduction in grain set per spikelet of winter wheat.

\begin{tabular}{|c|c|c|c|c|c|c|c|c|c|c|c|}
\hline & \multicolumn{7}{|c|}{ Mercia background } & \multicolumn{4}{|c|}{ Maris Widgeon background } \\
\hline & $\begin{array}{l}r h t \\
\text { (tall) }\end{array}$ & $\begin{array}{l}\text { Rht- } \\
\text { B1b }\end{array}$ & $\begin{array}{l}\text { Rht- } \\
\text { D1b }\end{array}$ & Rht 8 & $\begin{array}{l}\text { Rht- } \\
\text { B1C }\end{array}$ & $\begin{array}{l}\text { Rht- } \\
\text { D1c }\end{array}$ & Rht 12 & $\begin{array}{l}r h t \\
\text { (tall) }\end{array}$ & $\begin{array}{l}\text { Rht- } \\
\text { B1b }\end{array}$ & $\begin{array}{l}\text { Rht- } \\
\text { D1b }\end{array}$ & $\begin{array}{l}\text { Rht- } \\
\text { B1c }\end{array}$ \\
\hline \multicolumn{12}{|c|}{$\underline{\text { Timing } \times \text { NIL means }}{ }^{*}$} \\
\hline $\begin{array}{l}\text { Booting } \\
\text { St. error }\end{array}$ & $\begin{array}{c}33.4 \\
0.92\end{array}$ & $\begin{array}{c}33.4 \\
0.92\end{array}$ & $\begin{array}{c}29.4 \\
1.30\end{array}$ & $\begin{array}{c}32.8 \\
1.30\end{array}$ & $\begin{array}{c}33.8 \\
1.30\end{array}$ & $\begin{array}{c}24.1 \\
0.92\end{array}$ & $\begin{array}{c}27.5 \\
0.92\end{array}$ & $\begin{array}{c}28.6 \\
0.92\end{array}$ & $\begin{array}{c}30.1 \\
0.92\end{array}$ & $\begin{array}{c}30.3 \\
1.30\end{array}$ & $\begin{array}{c}28.5 \\
1.30\end{array}$ \\
\hline $\begin{array}{l}\text { Anthesis } \\
\text { St. error }\end{array}$ & $\begin{array}{c}32.1 \\
1.10\end{array}$ & $\begin{array}{c}30.3 \\
1.30\end{array}$ & $\begin{array}{c}29.7 \\
1.10\end{array}$ & $\begin{array}{c}29.6 \\
1.30\end{array}$ & $\begin{array}{c}28.8 \\
1.30\end{array}$ & $\begin{array}{c}24.3 \\
1.10\end{array}$ & $\begin{array}{c}31.3 \\
1.10\end{array}$ & $\begin{array}{c}32.5 \\
1.30\end{array}$ & $\begin{array}{c}32.7 \\
1.30\end{array}$ & $\begin{array}{c}33.6 \\
1.30\end{array}$ & $\begin{array}{c}33.8 \\
1.30\end{array}$ \\
\hline \multicolumn{12}{|c|}{ Irrigation $\times$ NIL means ${ }^{*}$} \\
\hline $\begin{array}{l}\text { No irrigation } \\
\text { St. error }\end{array}$ & $\begin{array}{c}30.5 \\
1.10\end{array}$ & $\begin{array}{c}30.1 \\
1.10\end{array}$ & $\begin{array}{c}24.3 \\
1.30\end{array}$ & $\begin{array}{c}33.0 \\
1.30\end{array}$ & $\begin{array}{c}30.0 \\
1.30\end{array}$ & $\begin{array}{c}23.9 \\
1.10\end{array}$ & $\begin{array}{c}26.4 \\
1.10\end{array}$ & $\begin{array}{c}27.3 \\
1.10\end{array}$ & $\begin{array}{c}29.4 \\
1.10\end{array}$ & $\begin{array}{c}28.9 \\
1.30\end{array}$ & $\begin{array}{c}26.3 \\
1.30\end{array}$ \\
\hline $\begin{array}{l}\text { Irrigated } \\
\text { St. error }\end{array}$ & $\begin{array}{c}35.0 \\
0.92\end{array}$ & $\begin{array}{c}33.6 \\
1.10\end{array}$ & $\begin{array}{c}34.7 \\
1.10\end{array}$ & $\begin{array}{c}29.4 \\
1.30\end{array}$ & $\begin{array}{c}32.5 \\
1.30\end{array}$ & $\begin{array}{c}24.5 \\
0.92\end{array}$ & $\begin{array}{c}32.3 \\
0.92\end{array}$ & $\begin{array}{c}33.9 \\
1.10\end{array}$ & $\begin{array}{c}33.4 \\
1.10\end{array}$ & $\begin{array}{c}35.0 \\
1.30\end{array}$ & $\begin{array}{c}36.1 \\
1.30\end{array}$ \\
\hline \multicolumn{12}{|l|}{ NIL Means $^{*}$} \\
\hline St. error & $\begin{array}{c}32.7 \\
0.72\end{array}$ & $\begin{array}{c}31.9 \\
0.80\end{array}$ & $\begin{array}{c}29.5 \\
0.85\end{array}$ & $\begin{array}{c}31.2 \\
0.92\end{array}$ & $\begin{array}{c}31.3 \\
0.92\end{array}$ & $\begin{array}{c}24.2 \\
0.72\end{array}$ & $\begin{array}{c}29.4 \\
0.72\end{array}$ & $\begin{array}{c}30.6 \\
0.80\end{array}$ & $\begin{array}{c}31.4 \\
0.80\end{array}$ & $\begin{array}{c}32.0 \\
0.92\end{array}$ & $\begin{array}{c}31.2 \\
0.92\end{array}$ \\
\hline
\end{tabular}

*Predicted means from an analysis of residual maximum likelihood (REML) 
Table 3 Effects of timing, irrigation and Rht allele within near-isogenic line (NILs) on the temperatures fitted to give a $50 \%$ reduction in grain set per spikelet of winter wheat.

\begin{tabular}{|c|c|c|c|c|c|c|c|c|c|c|c|}
\hline & \multicolumn{7}{|c|}{ Mercia background } & \multicolumn{4}{|c|}{ Maris Widgeon background } \\
\hline & $\begin{array}{l}r h t \\
\text { (tall) }\end{array}$ & $\begin{array}{l}\text { Rht- } \\
\text { B1b }\end{array}$ & $\begin{array}{l}\text { Rht- } \\
D 1 b\end{array}$ & Rht 8 & $\begin{array}{l}\text { Rht- } \\
\text { B1c }\end{array}$ & $\begin{array}{l}\text { Rht- } \\
\text { D1c }\end{array}$ & Rht 12 & $\begin{array}{l}r h t \\
\text { (tall) }\end{array}$ & $\begin{array}{l}\text { Rht- } \\
\text { B1b }\end{array}$ & $\begin{array}{l}\text { Rht- } \\
\text { D1b }\end{array}$ & $\begin{array}{l}\text { Rht- } \\
\text { B1C }\end{array}$ \\
\hline \multicolumn{12}{|c|}{ Timing $x$ NIL means ${ }^{*}$} \\
\hline $\begin{array}{l}\text { Booting } \\
\text { St. error }\end{array}$ & $\begin{array}{c}35.8 \\
0.84\end{array}$ & $\begin{array}{c}35.9 \\
0.84\end{array}$ & $\begin{array}{c}34.6 \\
1.05\end{array}$ & $\begin{array}{c}38.3 \\
1.05\end{array}$ & $\begin{array}{c}36.1 \\
1.05\end{array}$ & $\begin{array}{c}30.9 \\
0.84\end{array}$ & $\begin{array}{c}32.6 \\
0.84\end{array}$ & $\begin{array}{c}32.5 \\
0.84\end{array}$ & $\begin{array}{c}32.0 \\
0.84\end{array}$ & $\begin{array}{c}33.4 \\
1.05\end{array}$ & $\begin{array}{c}32.8 \\
1.05\end{array}$ \\
\hline $\begin{array}{l}\text { Anthesis } \\
\text { St. error }\end{array}$ & $\begin{array}{c}35.2 \\
0.91\end{array}$ & $\begin{array}{c}33.0 \\
1.05\end{array}$ & $\begin{array}{c}35.1 \\
0.91\end{array}$ & $\begin{array}{c}33.7 \\
1.05\end{array}$ & $\begin{array}{c}36.5 \\
1.05\end{array}$ & $\begin{array}{c}35.2 \\
0.91\end{array}$ & $\begin{array}{c}35.6 \\
0.91\end{array}$ & $\begin{array}{c}34.2 \\
1.05\end{array}$ & $\begin{array}{c}35.5 \\
1.05\end{array}$ & $\begin{array}{c}36.4 \\
1.05\end{array}$ & $\begin{array}{c}37.0 \\
1.05\end{array}$ \\
\hline \multicolumn{12}{|c|}{ Irrigation $\times$ NIL means ${ }^{*}$} \\
\hline $\begin{array}{l}\text { No irrigation } \\
\text { St. error }\end{array}$ & $\begin{array}{c}33.8 \\
0.92\end{array}$ & $\begin{array}{c}33.4 \\
0.93\end{array}$ & $\begin{array}{c}32.8 \\
1.05\end{array}$ & $\begin{array}{c}34.7 \\
1.05\end{array}$ & $\begin{array}{c}34.5 \\
1.05\end{array}$ & $\begin{array}{c}31.6 \\
0.92\end{array}$ & $\begin{array}{c}31.7 \\
0.92\end{array}$ & $\begin{array}{c}31.1 \\
0.93\end{array}$ & $\begin{array}{c}32.0 \\
0.93\end{array}$ & $\begin{array}{c}32.4 \\
1.05\end{array}$ & $\begin{array}{c}32.2 \\
1.05\end{array}$ \\
\hline $\begin{array}{l}\text { Irrigated } \\
\text { St. error }\end{array}$ & $\begin{array}{c}37.2 \\
0.81\end{array}$ & $\begin{array}{c}35.5 \\
0.92\end{array}$ & $\begin{array}{c}36.9 \\
0.91\end{array}$ & $\begin{array}{c}37.3 \\
1.05\end{array}$ & $\begin{array}{c}38.2 \\
1.05\end{array}$ & $\begin{array}{c}34.5 \\
0.81\end{array}$ & $\begin{array}{c}36.6 \\
0.81\end{array}$ & $\begin{array}{c}35.6 \\
0.92\end{array}$ & $\begin{array}{c}35.5 \\
0.92\end{array}$ & $\begin{array}{c}37.4 \\
1.05\end{array}$ & $\begin{array}{c}37.6 \\
1.05\end{array}$ \\
\hline \multicolumn{12}{|l|}{ NIL Means* } \\
\hline St. error & $\begin{array}{c}35.5 \\
0.72\end{array}$ & $\begin{array}{c}34.5 \\
0.72\end{array}$ & $\begin{array}{c}34.9 \\
0.78\end{array}$ & $\begin{array}{c}36.0 \\
0.80\end{array}$ & $\begin{array}{c}36.3 \\
0.85\end{array}$ & $\begin{array}{c}33.0 \\
0.85\end{array}$ & $\begin{array}{c}34.1 \\
0.72\end{array}$ & $\begin{array}{c}33.4 \\
0.72\end{array}$ & $\begin{array}{c}33.7 \\
0.78\end{array}$ & $\begin{array}{c}34.9 \\
0.78\end{array}$ & $\begin{array}{c}34.9 \\
0.85\end{array}$ \\
\hline
\end{tabular}

${ }^{*}$ Predicted means from an analysis of residual maximum likelihood (REML) 
Figure Legends

Fig. 1 effect of irrigation (open symbols = no irrigation; solid symbols = irrigated), timing of stress (circles = booting; squares = anthesis;) and temperature on the loss of mass per pot after three days in (A) 2011 and (B) in 2012. Error bar is maximum S.E.M.

Fig. 2 effect of dwarfing ( $R h t$ ) alleles varying for gibberellin (GA) sensitivity, increasing temperature, withholding water (open symbols, dashed line ), and timing of treatment on the grains per spikelet in near-isogenic lines of Mercia winter wheat. Fitted curves are logistic; inverted triangles are fitted temperature for $95 \%$ of maximum seed set; error bars in a, e, and s are one S.E.M for any point in the respective temperature and experiment.

Fig. 3 effect of dwarfing ( $R h t$ ) alleles varying for gibberellin (GA) sensitivity, increasing temperature, withholding water (open symbols, dashed line ), and timing of treatment on the grains per spikelet in near-isogenic lines of Maris Widgeon winter wheat. Fitted curves are logistic; inverted triangles are fitted temperature for $95 \%$ of maximum seed set; error bars in a and i are one S.E.M for any point in the respective temperature and experiment. 